\title{
Manifestações do setor turístico em Praia Grande (SC) no início do século XXI
}

Manifestations of the tourism sector in Praia Grande (SC) at the beginning of the 21 st century

\author{
Hoyêdo Nunes Lins \\ hnlins@cse.ufsc.br \\ Universidade Federal de Santa Catarina (UFSC) \\ Paulo Fernandes Kieling da Rocha \\ paulo.fkieling@terra.com.br \\ Universidade Federal de Santa Catarina (UFSC)
}

\begin{abstract}
Resumo: A leste da fronteira entre Santa Catarina e Rio Grande do Sul há um grande complexo de cânions que integra os atrativos turísticos do sul do Brasil e recebe sobretudo interessados em ecoturismo e turismo de aventuras. No lado catarinense, Praia Grande é passagem praticamente obrigatória para quem demanda esse patrimônio, o que confere sentido à ideia de que o setor de turismo tem presença nesse município. $\mathrm{O}$ estudo aborda tal assunto procurando caracterizar Praia Grande como destino turístico e oferecer uma ideia sobre reflexos socioeconômicos locais. Mostra-se que o município recebe visitantes oriundos de vários estados brasileiros e países e que a oferta de serviços turísticos (hospedagem, alimentação) cresceu rapidamente desde meados dos anos 2000. No plano institucional, as medidas de promoção e planejamento do setor têm sido tímidas, longe de representarem um real engajamento na expansão do setor.
\end{abstract}

Palavras-chave: Complexo de Cânions; Turismo; Praia Grande (SC)

Código JEL: Z32.

\begin{abstract}
On the Eastern part of the border between Santa Catarina and Rio Grande do Sul, there is an important complex of canyons that attracts mainly visitors interested in ecotourism and adventure tourism. In Santa Catarina, Praia Grande is a practically obligatory way towards the canyons area, and this fact seems to mean that the tourism sector is present in this municipio. This study addresses this subject trying both to portray Praia Grande as a touristic destination and to explore some hints concerning social and economic outcomes. It is indicated that Praia Grande receives tourists from different parts of Brazil and other countries, and that its offer of touristic services grew rapidly since the mid-2000s. In institutional terms, some measures for tourism promotion and planning have been witnessed, but they appear to be timid and far from representing a real involvement with tourism development.
\end{abstract}

Keynotes: Complex of Canyons; Tourism; Praia Grande (SC)

JEL Code: Z32.

Recebido em: 27-03-2018. Aceito em: 22-05-2018.

\section{INTRODUÇÃO}

É quase lugar comum, mesmo entre observadores que se interessam minimamente pelo assunto, dizer que o turismo sobressai entre os setores que mais cresceram na segunda metade do século XX, em nível mundial. Enfeixaram-se no seu robustecimento, entre outros aspectos, as melhorias progressivas nas condições de transporte e comunicação e os avanços institucionais. 


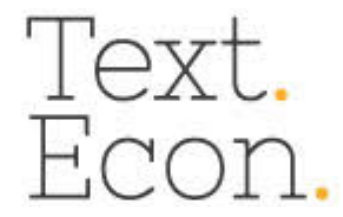

Ambos os fatores ajudaram a colocar a evasão da rotina do cotidiano, favorecida pelas viagens, no centro do usufruto dos tempos de não-trabalho de numerosos indivíduos. O setor ganhou, de fato, importância na sociedade industrial, pelo seu significado na recomposição da capacidade das pessoas para lidar com os desafios da vida diária, conforme a sugestiva formulação de Krippendorf (1989).

Ao mesmo tempo, em vários ambientes dotados de atrativos turísticos, passou-se a apostar nesse setor como instrumento de estímulo à economia, assimilado a possíveis movimentos em espiral envolvendo investimentos, renda, empregos e tributos, o conjunto podendo propiciar mudanças rumo ao desenvolvimento. A sedução desses acenos tende a ser quase irresistível, fazendo o turismo ganhar proeminência em políticas e estratégias executadas em diferentes latitudes, sem que o Brasil - e Santa Catarina - represente exceção.

Assim, diversos recursos dos territórios capturados pelo otimismo sobre o setor turístico têm sido explorados. Têm realce aqueles vinculados aos atributos físicos e naturais, mostrando igualmente importância os aspectos históricos e culturais, entre outros. Em meio aos recursos que proporcionam ou escoram a promoção de atividades turísticas, perfilam-se os acidentes geográficos ou formas de relevo peculiares, como diferentes experiências permitem constatar. É ilustração o Grand Canyon, no estado do Arizona, nos Estados Unidos, assim como a Cordilheira dos Andes, na América do Sul, o Maciço Alpino (ou simplesmente Alpes), na Europa, as Cataratas do Iguaçu, na fronteira do Brasil (estado do Paraná) com a Argentina, e as Niagara Falls, no leste da América do Norte, na fronteira dos Estados Unidos (estado de New York) com o Canadá.

Na Região Sul do Brasil, mais propriamente na extremidade leste da divisa entre Santa Catarina e Rio Grande do Sul, observa-se conjunto de cânions que ostenta inegável destaque, até em escala de América do Sul. O local registra paisagens que abrangem maciços com alturas de até 1.400 metros, paredões, rios e cachoeiras. Não surpreende que esses atributos naturais tenham ensejado a criação, em 1959, do Parque Nacional de Aparados da Serra e, contiguo a este, em 1992, do Parque Nacional da Serra Geral.

No lado catarinense de tal estrutura geológica e paisagística, o município de Praia Grande se destaca no entorno do complexo de cânions. Trata-se do município com, possivelmente, as maiores e melhores estruturas urbanas e de serviços na vizinhança próxima. Isso tem resultado em fluxos de visitantes motivados pelo interesse em conhecer o referido patrimônio físiconatural, com práticas assimiláveis ao turismo de aventuras ou ao turismo ecológico, haja vista o existente leque de possibilidades. 


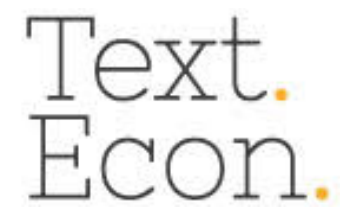

Esses aspectos subjazem à definição do tema cuja pesquisa nutriu a preparação deste artigo. O problema da pesquisa é o grau e a forma de envolvimento de Praia Grande com o setor turístico, dando-se ênfase aos processos que marcaram a respectiva trajetória no presente século. O objetivo geral é caracterizar a localidade como destino de turistas, uma condição indissociável da sua contiguidade ao complexo de cânions. Caracterizar Praia Grande dessa forma implica perscrutar os reflexos no território municipal, principalmente em termos de surgimento ou expansão de serviços turísticos, da situação local como passagem praticamente obrigatória, em Santa Catarina, para quem busca aqueles atrativos. A questão reveste-se tanto mais de interesse porque o município encontra-se em região - o extremo sul catarinense - de limitada base econômica, conforme assinalado por estudos como Lins e Santos (2013). Não carece de sentido imaginar que o turismo pode se tornar uma alternativa para o local, no que respeita a investimentos, geração de renda e ocupação da mão de obra.

A pesquisa envolveu trabalho de campo, para obtenção de dados e informações, junto aos integrantes do trade turístico de Praia Grande (meios de hospedagem, estabelecimentos voltados à alimentação, agências de viagens e turismo) e também a instituições como a Prefeitura Municipal. Esse levantamento ocorreu durante o segundo semestre de 2017, no essencial. Consultas a documentos, como o Livro de Registros do Portal Turístico de Praia Grande, e informações disponibilizadas nas páginas na internet de órgãos públicos e de empreendimentos ligados ao turismo complementaram a base sobre a qual se elaborou o estudo.

A estrutura do texto contém seis seções, incluindo a Introdução e as Considerações Finais. Na seção 2 caracteriza-se Praia Grande em termos socioeconômicos e se realçam os elementos da sua oferta turística, mormente os serviços de hospedagem e alimentação. Na seção 3 fala-se da demanda turística, explorando as possibilidades de análise associadas aos dados disponibilizados no município. Na seção 4 arrisca-se um exercício de estimativa dos reflexos econômicos do turismo, utilizando informações obtidas junto aos meios de hospedagem e outros serviços, por entrevistas ou nas respectivas páginas na internet. Na seção 5, a última antes das Considerações Finais, aborda-se a face, por assim dizer, institucional do turismo em Praia Grande, falando da atuação da Prefeitura Municipal na organização de eventos e no envolvimento em iniciativas (regionais ou não) de planejamento ou promoção do setor.

\section{PRAIA GRANDE: ESBOÇO DE CARACTERIZAÇÃO}




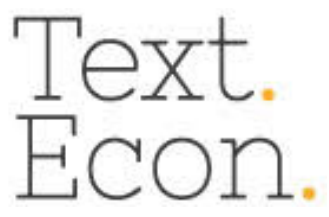

Praia Grande resultou de emancipação do município de Turvo, em 1958, mas já no início do século XX o local registrava a presença de colonizadores, como outras localidades do extremo sul catarinense (HOBOLD, 1994). Entre os pioneiros figuravam comerciantes e agentes de transformação agroindustrial em torrefação e moagem de café, descasque de arroz e produção de derivados da cana de açúcar (rapadura, açúcar, cachaça), comercializados na própria área e na região serrana do Rio Grande do Sul (RONSANI, 1999). O município integra a microrregião de Araranguá e a Associação dos Municípios do Extremo Sul Catarinense (AMESC). Da segunda também fazem parte Araranguá, Balneário Arroio do Silva, Balneário Gaivota, Ermo, Jacinto Machado, Maracajá, Meleiro, Morro Grande, Passo de Torres, Santa Rosa do Sul, São João do Sul, Sombrio, Timbé do Sul e Turvo. A Figura 1 permite observar a localização de Praia Grande em Santa Catarina.

Figura 1 - Estado de Santa Catarina: localização do município de Praia Grande

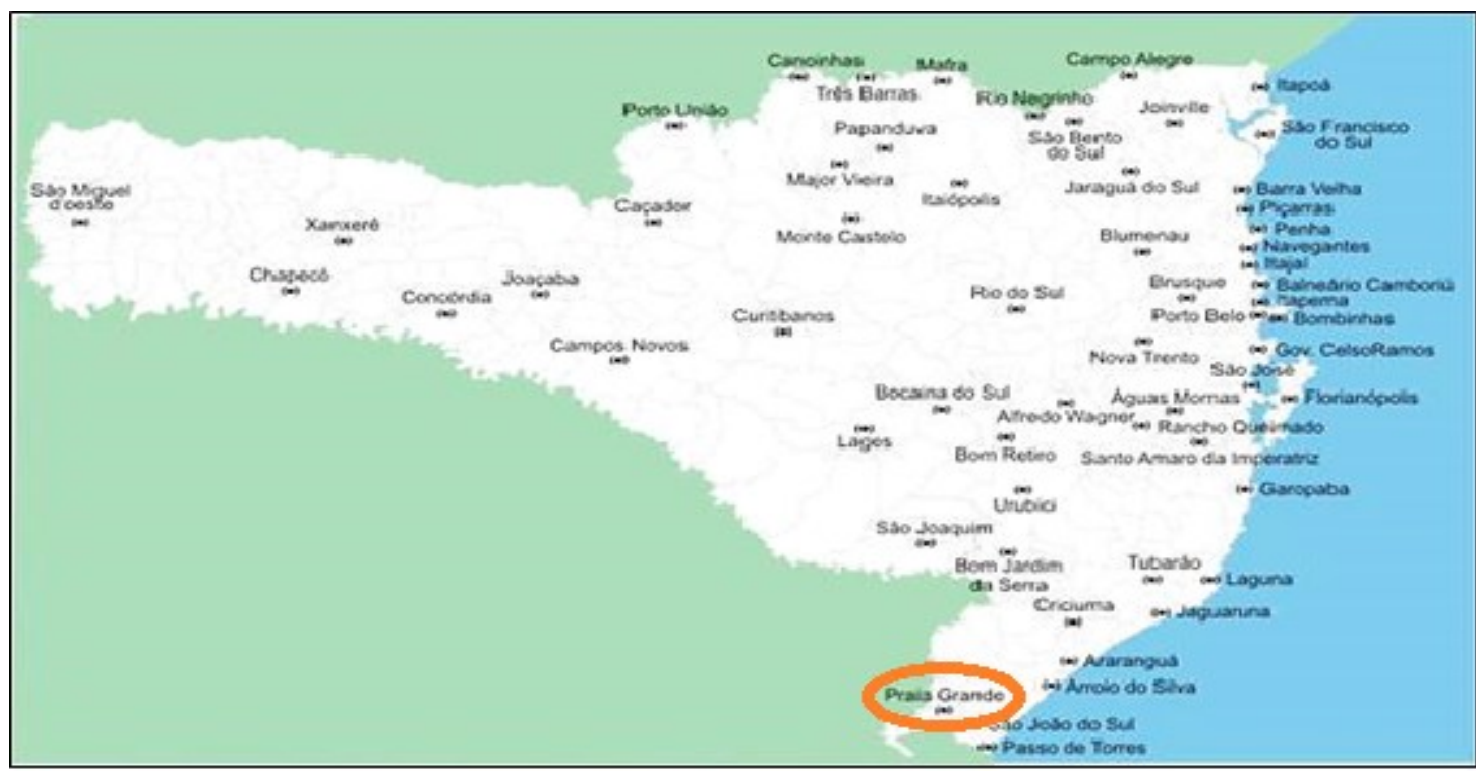

Fonte: elaborado pelos autores com base em material disponibilizado por EncontraSC ([S.l.];[S.d.])

Em terras catarinenses, Praia Grande faz fronteira com Jacinto Machado, Santa Rosa do Sul e São João do Sul, ao norte, a leste e ao sul, nesta ordem. Em território gaúcho o limite implica Mampituba, na direção sul, e Cambará do Sul, através do Parque Nacional de Aparados da Serra e do Parque Nacional da Serra Geral. Assim, parte de seu território situa-se nas áreas desses parques, como se vê na Figura 2, refletindo-se em relevo municipal com altitudes que variam entre 45 e 1.000 metros. Sua vegetação característica refere-se à Mata Atlântica, e sua área encontra-se na bacia hidrográfica do Rio Mampituba, um desaguadouro de vários afluentes. 


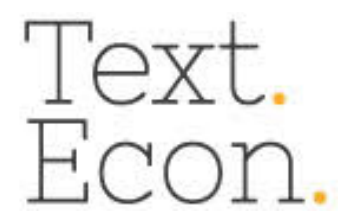

Figura 2 - Praia Grande e a área de cânions

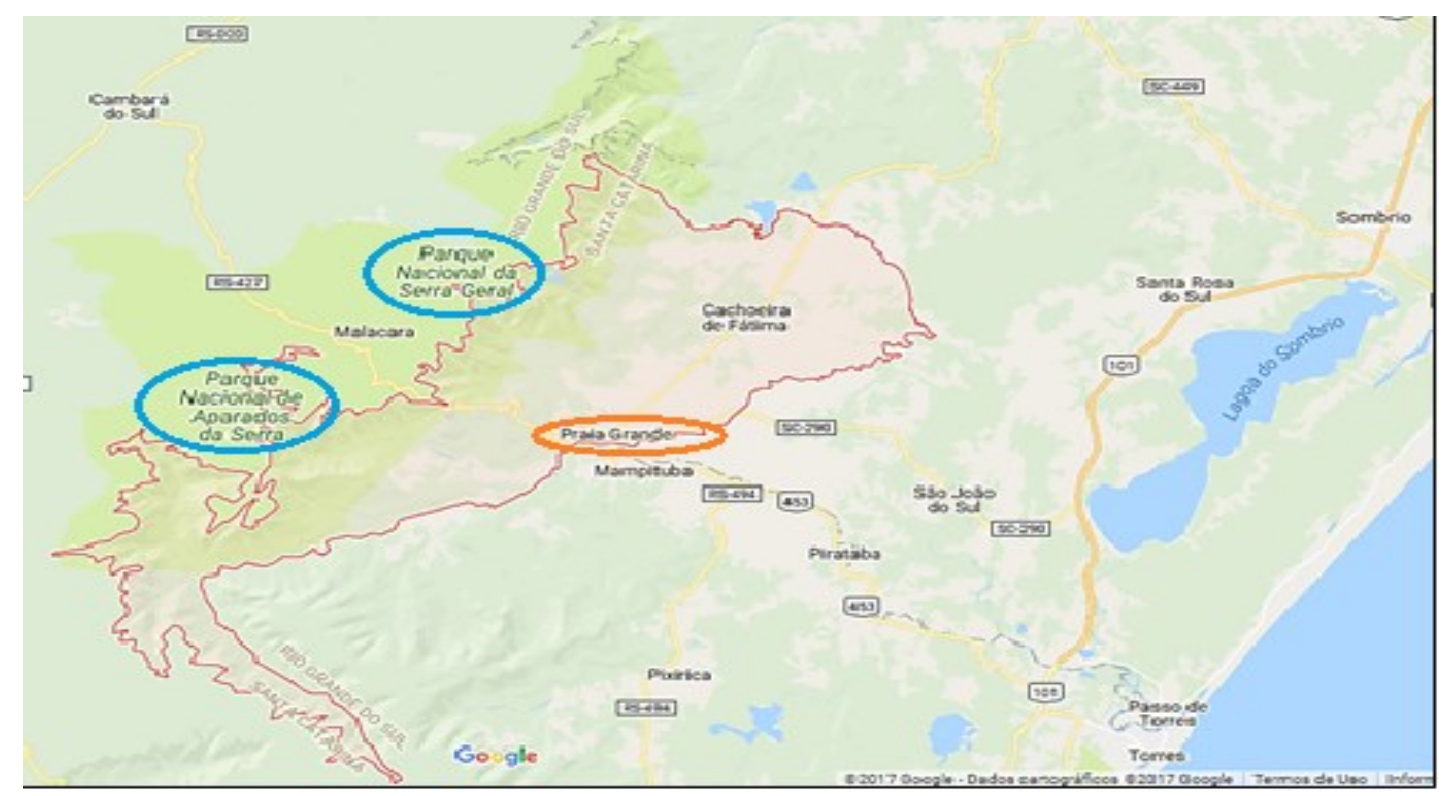

Fonte: elaborado pelos autores com base em material disponibilizado em Mapa de Praia Grande-SC ([S.d.],

$\mathrm{Na}$ sequência apresentam-se algumas informações que, de algum modo, permitem caracterizar Praia Grande em termos socioeconômicos.

\subsection{Caracterização socioeconômica}

A população municipal era de 7.267 habitantes em 2010, pelo correspondente Censo Demográfico, representando participação no total da AMESC inferior a 4\% (Tabela 1). A maior população dizia (e diz) respeito ao município de Araranguá (61.310 habitantes), seguido de longe por Sombrio (26.613), juntos representando 48\% do total. Em Praia Grande, 59\% das pessoas vivem na área urbana, nível que supera apenas o de metade dos municípios da microrregião pelo critério da taxa de urbanização, mas que representa grande diferença frente a São João do Sul (22\%), Morro Grande (26\%), Ermo (30\%) e Timbé do Sul (31\%), principalmente. Nos últimos 40 anos, pelos dados do Censo Demográfico desde 1970, Praia Grande exibiu contínua redução populacional, expressa em números absolutos e em participação no conjunto de Santa Catarina e 


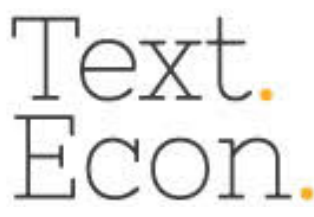

na AMESC. Em relação à segunda, o recuo de 7,57\% em 1970 para 3,97\% em 2010 espelha igualmente, além da própria evasão, uma forte tendência de "litoralização" regional, salientada em diferentes estudos (LINS; SANTOS, 2013).

Tabela 1 - Praia Grande, Associação dos Municípios do Extremo Sul Catarinense (AMESC) e Santa Catarina: trajetória da população total entre 1990 e 2015

\begin{tabular}{cccccc}
\hline Ano & $\begin{array}{c}\text { Praia Grande } \\
(\mathrm{A})\end{array}$ & $\begin{array}{c}\text { AMESC } \\
(\mathrm{B})\end{array}$ & $\begin{array}{c}\text { Santa Catarina } \\
(\mathrm{C})\end{array}$ & A:B * 100 & A:C * 100 \\
\hline 1970 & 8.140 & 107.510 & 2.901 .660 & 7,57 & 0,28 \\
1980 & 7.608 & 111.267 & 3.628 .292 & 6,84 & 0,21 \\
1991 & 7.579 & 139.584 & 4.538 .240 & 5,43 & 0,16 \\
2000 & 7.286 & 162.349 & 5.349 .580 & 4,49 & 0,13 \\
2010 & 7.267 & 182.818 & 6.248 .360 & 3,97 & 0,11 \\
\hline
\end{tabular}

Fonte: elaborado pelos autores com dados dos Censos Demográficos do IBGE (vários anos)

Uma ideia sobre a estrutura da economia municipal pode ser obtida pela observação do Valor Adicionado Bruto (VAB) e do Valor Adicionado Fiscal (VAF). O primeiro informa sobre a contribuição de cada setor da economia para o Produto Interno Bruto (PIB). O segundo, que responde por $85 \%$ da composição do índice de retorno aos municípios do Imposto sobre a Circulação de Mercadorias e Serviços (ICMS), pode ser tomado como indicativo, de alguma maneira, do perfil econômico local.

Dados disponíveis em IBGE ([S.d.]a) mostram que no ano de 2015 o VAB de Praia Grande exibia a agropecuária com 15\% do total, a indústria com 14,6\%, os serviços (excetuados administração, defesa, educação, saúde pública e seguridade social) com 46,4\% e o conjunto de administração, defesa, educação, saúde pública e seguridade social com 23,9\%. Quanto ao VAF, o perfil pode ser observado na tabela 2, que apresenta a arrecadação, em 2015, das 25 principais atividades econômicas do município. Cabe ressaltar as atividades 551 e 561, relativas, respectivamente, a meios de hospedagem e serviços de alimentação, diretamente vinculadas ao assunto desta pesquisa: em 2015 , os respectivos VAF, somados, não ultrapassaram $0,9 \%$ do total para o conjunto das atividades mostradas. 


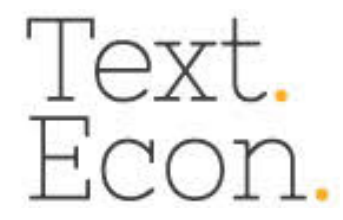

http://dx.doi.org/10.5007/2175-8085.2018v21n2p119

Tabela 2 - Praia Grande: Valor Adicionado Fiscal (VAF) das 25 atividades mais importantes (2015)

\begin{tabular}{|c|c|c|c|}
\hline $\begin{array}{l}\text { Grupo } \\
\text { CNAE }\end{array}$ & Descrição da atividade & $\begin{array}{l}\text { Valor do VAF } \\
(\mathrm{R} \$)\end{array}$ & $\%$ \\
\hline 980 & Produção Primária & $28.072 .533,19$ & 39,2 \\
\hline 222 & Fabricação de produtos de material plástico & $9.550 .482,98$ & 13,3 \\
\hline 351 & Geração, transmissão e distribuição de energia elétrica & $4.911 .859,30$ & 6,8 \\
\hline 471 & Comércio varejista não especializado & 4.174.164,40 & 5,8 \\
\hline 477 & Comércio varejista de produtos farmacêuticos, perfumaria. & 2.604.251,96 & 3,6 \\
\hline 475 & Comércio varejista de equipam. de informática e comunicação & $2.512 .439,75$ & 3,5 \\
\hline 474 & Comércio varejista de material de construção & $2.200 .768,32$ & 3,1 \\
\hline 478 & Comércio varejista de produtos novos não especificados & 2.091.306,42 & 2,9 \\
\hline 473 & Comércio varejista de combustíveis para veículos automotores & $1.997 .703,56$ & 2,8 \\
\hline 162 & Fabricação de produtos de madeira, cortiça e material trançado & $1.997 .370,13$ & 2,8 \\
\hline 611 & Telecomunicações por fio & $1.873 .903,92$ & 2,6 \\
\hline 254 & Fabricação de artigos de cutelaria, de serralheria e ferramentas & $1.215 .354,69$ & 1,7 \\
\hline 259 & Fabric. de produtos de metal não especificados anteriormente & $1.125 .256,20$ & 1,6 \\
\hline 109 & Fabricação de outros produtos alimentícios & $848.169,27$ & 1,2 \\
\hline 612 & Telecomunicações sem fio & $716.807,27$ & 1,0 \\
\hline 468 & Comércio atacadista especializado em outros produtos & $661.454,30$ & 0,9 \\
\hline 106 & Moagem, fabric. de prod. amiláceos e de alimentos para animais & $598.654,87$ & 0,8 \\
\hline 141 & Confecção de artigos do vestuário e acessórios & $470.857,06$ & 0,6 \\
\hline 476 & Comércio varejista de artigos culturais, recreativos e esportivos & $459.093,71$ & 0,6 \\
\hline 101 & Abate e fabricação de produtos de carne & $434.576,06$ & 0,6 \\
\hline 453 & Comércio de peças e acessórios para veículos automotores & $429.460,63$ & 0,6 \\
\hline 561 & Restaurantes e outros serviços de alimentação e bebidas & $379.062,25$ & 0,5 \\
\hline 161 & Desdobramento de madeira & $320.460,80$ & 0,4 \\
\hline 551 & Hotéis e similares & $302.446,08$ & 0,4 \\
\hline \multirow[t]{2}{*}{493} & Transporte rodoviário de carga & $216.422,70$ & 0,3 \\
\hline & Total das atividades & $70.164 .859,82$ & 100 \\
\hline
\end{tabular}

Fonte: elaborado pelos autores com dados de Governo de Santa Catarina ([S.d.])

Obs.: os totais do VAF das 25 atividades citadas somam R $\$ 70.164 .859,82$, representando $98 \%$ de um total geral de $\mathrm{R} \$ 71.627 .582,63$

No setor primário, o grande destaque entre as lavouras temporárias é o cultivo de arroz, conforme dados para 2016 (IBGE, [S.d.]b), seguido do fumo e do milho; nas lavouras permanentes, banana e maracujá mostram importante presença. No setor secundário, envolvendo empresas de pequeno ou médio porte, dados sobre o VAF em 2015 (GOVERNO DE SANTA CATARINA, [S.d]) indicam a proeminência dos produtos de material plástico, cujas fábricas VF Marmorite (pias, tanques, lavatórios), Sirinaica (componentes e peças, sobretudo, para a 


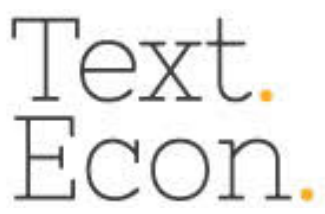

indústria automotiva) - eram importantes empregadoras. Também sobressai a fabricação de produtos de madeira, como esquadrias residenciais (Madefa), e de artigos de cutelaria e outros acessórios para cozinhas (Modefer Inox). O setor terciário se manifesta em várias atividades, sendo que $3 / 4$ do seu VAF disseram respeito, em 2015, à soma das modalidades de comércio varejista; os serviços de hospedagem e alimentação atingiram, juntos, 3,2\% (GOVERNO DE SANTA CATARINA, [S.d.]).

Dados de empregos formais, oriundos da Relação Anual de Informações Sociais (RAIS), do Ministério do Trabalho, enriquecem essa caracterização de Praia Grande. Quase 41\% dos 1.323 vínculos empregatícios ativos registrados em 31/12/2016, pela classificação de atividades IBGE Setor (8 níveis), referiam-se à indústria de transformação. A administração pública reunia pouco mais de $1 / 5$, o comércio, pouco mais de $16 \%$, e os serviços, quase 14\% (Figura 3). Esses números não cobrem toda a realidade das ocupações, pois dizem respeito somente aos vínculos formais. Todavia, representando, por assim dizer, um "piso quantitativo", permitem uma ideia sobre a situação do trabalho local.

Figura 3 - Praia Grande: vínculos empregatícios ativos em 31/12/2016 (\%) - Classificação IBGE Setor
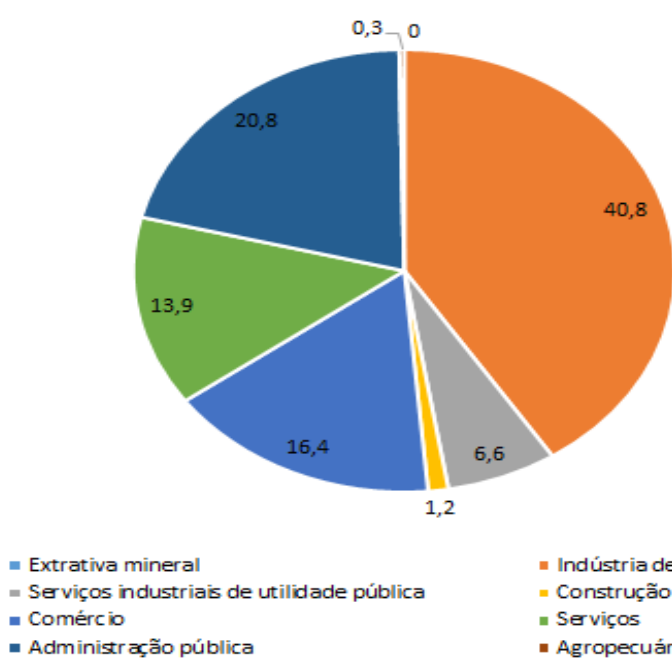

- Indústria de transformação

- Construção civil

- Serviços

- Administr ação pública

- Agropecuária, extração vegetal, caça e pesca

Fonte: elaborado pelos autores com dados da Relação Anual de Informações Sociais (RAIS) para 2016 (MINISTÉRIO DO TRABALHO, [S.d.]

Praia Grande apresenta-se, assim, como localidade que padece de limitada base econômica e de escasso dinamismo. A própria trajetória populacional é sugestiva das condições locais e, principalmente, do modo como os habitantes têm percebido, ao longo do tempo, as possibilidades de reprodução social no município. O patamar do Índice de Desenvolvimento Humano Municipal (IDHM) parece um bom indicativo sobre o quadro. É verdade que o IDHM 


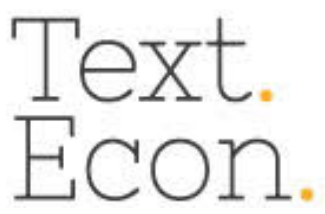

http://dx.doi.org/10.5007/2175-8085.2018v21n2p119

de Praia Grande cresceu uma vez e meia em duas décadas, passando de 0,465, em 1991, para 0,598, em 2000, e para 0,718 em 2010, com evolução desde a categoria "muito baixo" para a categoria "alto" (PNUD; FUNDAÇÃO JOÃO PINHEIRO; IPEA, 2013). Mas seu nível nunca suplantou a média catarinense, escala em que o IDHM foi de 0,543 em 1992, de 0,674 em 2000 e de 0,774 em 2010.

A caracterização de Praia Grande quanto à presença de condições para turismo ocupa a subseção a seguir.

\subsection{Atributos e recursos para turismo}

A oferta turística original de Praia Grande, representando os atrativos primários do território, refere-se ao complexo de cânions do Parque Nacional de Aparados da Serra e do Parque Nacional da Serra Geral, como assinalado. Sua condição de destino turístico prende-se às belezas naturais dessas formações geológicas e às possibilidades de sua exploração por trilhas, assim como ao desfrute da própria paisagem, que inclui vales, cursos d'água, cachoeiras e um amplo espectro do binômio flora-fauna.

Os cânions de maior destaque são o Itaimbezinho e o da Fortaleza, com vales que se estendem por muitos quilômetros. O reconhecimento de que seus ecossistemas interiores são frágeis levou à criação dos parques mencionados, sendo que o de Aparados da Serra abriga o cânion do Itaimbezinho, e o da Serra Geral, o da Fortaleza. A rigor, existem na região de Praia Grande várias dessas formações, alcançadas por caminhos de extensões e condições (dificuldades) diversas, seja na parte catarinense ou na gaúcha (pelo município de Cambará do Sul). Além dos já mencionados, há igualmente os cânions de Malacara, Índios Coroados, Faxinalzinho, Churriado, Leão e Molha Cocos.

Os atributos locais propiciam práticas turísticas assimiláveis, notadamente, às modalidades ecoturismo e turismo de aventura. Ambas integram, no seu avanço internacional, movimento chamado de "turismo pós-moderno" por alguns autores, distanciando-se do paradigma tradicional do turismo de massa (LINS, 2013). No ecoturismo, princípios como zelo pela sustentabilidade e integração homem-natureza aparecem como aspectos básicos. No turismo de aventura, que pode ser entendido como uma derivação do anterior, o trato com os desafios impostos pelas condições locais, exigindo esforço físico, condicionamento e habilidades, constitui elemento característico.

Essa oferta primária resulta em "consumo", no tocante ao papel de Praia Grande como parte do território turístico cujo epicentro é o complexo de cânions, porque serviços de, 


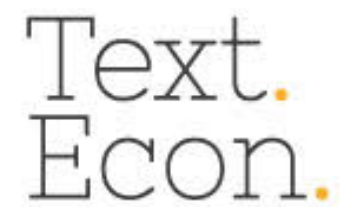

principalmente, hospedagem e alimentação floresceram no local. A expansão dessa oferta - de índole "incorporada" ou "derivada" frente à primária - foi quase linear desde a virada do século. $\mathrm{Na}$ base desse processo figura, certamente, a estrutura para recepção de visitantes instalada quando da reabertura dos parque em 1998, após período de embates, envolvendo grupos ambientalistas e o Ministério Público Federal, que resultara no fechamento em 1996. Com a reabertura, convênios entre o Instituto Brasileiro do Meio Ambiente e dos Recursos Naturais Renováveis (IBAMA), o Governo do Rio Grande do Sul e o Instituto Brasileiro do Turismo (EMBRATUR) foram estabelecidos no intuito de criar infraestrutura que permitisse utilização turística. Esta foi posteriormente realçada no próprio âmbito do Ministério do Meio Ambiente e do vinculado Instituto Chico Mendes de Conservação da Biodiversidade (ICMBio), que passou a administrar os parques, considerados unidades de conservação. Foi a partir da reabertura, e na esteira dessa sinalização relativamente ao uso turístico, que pousadas e outros serviços de recepção turística passaram a surgir na região, como aponta Brightwell (2006). Ajudou a consolidar essa trajetória o marketing turístico, protagonizado nos anos seguintes e em curso até os dias atuais, conforme se pode observar em Ministério do Turismo (2017).

Nos meios de hospedagem, até o final da década de 1990 havia somente uma opção em Praia Grande: o Hotel do Sérgio, criado em 1989. No presente século, quase a cada ano um novo empreendimento - a maior parte do tipo pousada - foi instalado. Na grande maioria na forma de iniciativas locais, como empreendimentos familiares amparados por recursos próprios e com gestão também familiar (excetuados dois negócios oriundos de investidas extralocais, de perfil efetivamente empresarial), até 2015 esse processo representou uma oferta agregada de 127 unidades habitacionais e 406 leitos (Tabela 3). Vale assinalar, igualmente, que os proprietários dos meios de hospedagem locais criaram em 2013 a Associação Praiagrandense dos Empresários do Turismo (APETUR).

Trajetória mais ou menos parecida caracteriza os serviços de alimentação. Sobretudo desde meados da década de 2000, uma tendência de criação praticamente anual de novos serviços dessa natureza esteve em curso, abrangendo restaurantes, pizzarias e cafés. Alguns funcionam nos próprios meios de hospedagem, integrando as estruturas destes, as origens locais ou extralocais - refletindo a correspondente condição dos serviços de hospedagem (Tabela 4). A maioria apresenta o mesmo perfil do maior número dos meios de hospedagem, ou seja, tipo de iniciativa que floresceu na esfera familiar. 


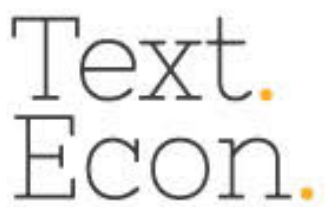

Tabela 3 - Praia Grande: aspectos da oferta de hospedagem criada até 2015

\begin{tabular}{|c|c|c|c|c|c|}
\hline Estabelecimento & Tipo & $\begin{array}{c}\text { Início } \\
\text { das } \\
\text { atividades }\end{array}$ & $\begin{array}{c}\mathrm{N}^{\mathrm{o}} \mathrm{de} \\
\text { unidades } \\
\text { habitacion. }\end{array}$ & $\begin{array}{c}\mathrm{N}^{\mathrm{o}} \\
\mathrm{de} \\
\text { leitos }\end{array}$ & $\begin{array}{l}\text { Origem } \\
\text { do } \\
\text { negócio }\end{array}$ \\
\hline Hotel do Sérgio & Hotel & 1989 & 14 & 32 & Local \\
\hline Pousada Colina da Serra & Pousada & 2000 & 6 & 22 & Local \\
\hline Refúgio Ecológico Pedra Afiada & Pousada & 2001 & 19 & 62 & Externa \\
\hline Costão da Fortaleza Lodge & Pousada & 2001 & 5 & 17 & Local \\
\hline Pousada Morada dos Canyons & Pousada & 2004 & 10 & 30 & Local \\
\hline Hostel Nativo dos Canyons & Hostel & 2005 & 4 & 14 & Local \\
\hline Praia Grande Hotel & Hotel & 2006 & 15 & 51 & Local \\
\hline Resort dos Canyons & Resort & 2007 & 3 & 10 & Local \\
\hline Pousada Malacara & Pousada & 2008 & 11 & 22 & Local \\
\hline Pousada Pacatatu & Pousada & 2009 & 5 & 10 & Local \\
\hline Pousada Aracema & Pousada & 2011 & 12 & 48 & Externa \\
\hline Pousada Lima & Pousada & 2012 & 7 & 21 & Local \\
\hline Refúgio das Montanhas & Pousada & 2013 & 5 & 18 & Local \\
\hline Chalés Pousada Itaimbé & Pousada & 2015 & 8 & 24 & Local \\
\hline Hospedaria Regional Beija Flor & Hospedaria & 2015 & 3 & 25 & Local \\
\hline Total & & & 127 & 406 & \\
\hline
\end{tabular}

Tabela 4 - Praia Grande: trajetória de criação de serviços de alimentação entre 2000 e 2015

\begin{tabular}{lcc}
\hline \multicolumn{1}{c}{ Estabelecimento } & Início das atividades & Origem do negócio \\
\hline Lancheria Cachoeira da Serra & 2000 & Local \\
Pedra Afiada & 2001 & Externa \\
Casarão Pizzaria & 2006 & Local \\
Casa Nossa Restaurante Rural & 2007 & Local \\
Resort dos Canyons & 2007 & Local \\
Restaurante Malacara & 2008 & Local \\
Restaurante do Carlinhos & 2010 & Local \\
A Casa do Sabor & 2011 & Local \\
Café Rural e Camping Rio do Boi & 2012 & Local \\
Pizzaria Opinião & 2013 & Local \\
Urca Café e Sorveteria & 2013 & Local \\
Casa do Petysco & 2014 & Externa \\
\hline
\end{tabular}

Fonte: elaborado pelos autores com base em pesquisa de campo e nas informações disponíveis em Prefeitura de Praia Grande ([S.d.)b]

Praia Grande também registra a atuação de agências de viagem e turismo e de guias turísticos. Estes são profissionais necessários à adequada realização das práticas de ecoturismo e turismo de aventuras nos cânions. Em parcerias com pousadas e hoteis, as agências protagonizam intermediação entre esses estabelecimentos e os turistas, fornecendo serviços de translado, guia e acompanhamento, e também comercializam pacotes que incluem passeios a cavalo, caminhadas em trilhas e prática de rapel, entre outros atrativos. 


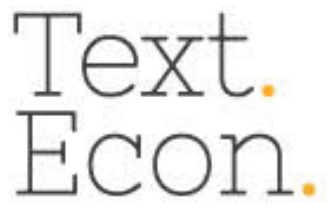

Como se observa na tabela 5, o processo de criação dessas agências ganhou algum vigor somente após o fim da década de 2010. Até 2009, a operadora Rota dos Canyons atuou praticamente sozinha, e só então instalou-se processo de abertura de uma nova agência a cada ano, praticamente, sobressaindo 2015, com quatro novas empresas.

Tabela 5 - Praia Grande: agências de viagem e turismo instaladas até 2015

\begin{tabular}{lcc}
\hline \multicolumn{1}{c}{ Agência de viagem e turismo } & $\begin{array}{c}\text { Início das } \\
\text { atividades }\end{array}$ & $\begin{array}{c}\text { Quantidade de } \\
\text { guias disponíveis }\end{array}$ \\
\hline Rota dos Canyons & 2001 & 2 \\
Verdes Canyons & 2009 & 3 \\
Canyons e Peraus & 2010 & 6 \\
Canyons do Sul & 2011 & 1 \\
Aparados Turismo Receptivo & 2013 & 1 \\
Leão Baio & 2014 & 1 \\
Trip dos Canyons & 2015 & 1 \\
Turismo Serra Geral & 2015 & 1 \\
Tribo dos Canyons & 2015 & 1 \\
\hline Total & & 17 \\
\hline
\end{tabular}

Fonte: elaborado pelos autores com base em pesquisa de campo e em informações disponíveis em Prefeitura de Praia Grande ([S.d.]c)

Cabe, todavia, uma observação sobre o assunto. Desde o final dos anos 1990, o serviço de guias implicava a Associação Praiagrandense de Condutores para Ecoturismo (APCE), fundada em 1998 por imposição do ICMBio. Na reabertura do Parque Nacional de Aparados da Serra, aquela instituição exigiu que a utilização das trilhas e o usufruto dos atributos locais contassem com guias pertencentes a uma associação da categoria. Entretanto, entrevistas realizadas com alguns guias, durante a pesquisa de campo, indicaram que a referida associação sofreu esvaziamento, pois muitos profissionais passaram a atuar por conta própria. Assim, a multiplicação das agências de viagem e turismo constitui um reflexo desse quadro, devendo-se assinalar que quase todas foram criadas por membros (ou antigos membros) daquela associação.

As entrevistas com os guias indicaram que seus serviços geralmente se intensificam entre o feriado de 15 de novembro e o final do mês de março. A incidência, via de regra, é nos fins de semana: segundo a pesquisa realizada junto aos serviços de hospedagem, é de dois pernoites a permanência média dos visitantes, o check in ocorrendo a partir das 12:00 da sexta feira, e o check out, após as 13:00 do domingo. Pelas informações, um único final de semana com muitos turistas pode representar trabalho como guia para grupos de 30 pessoas, mais ou menos; na maior parte do ano o número observado gira em torno de 5 turistas, na média mensal. Por conta disso, os guias de Praia Grande também costumam desempenhar outras atividades profissionais. O que se pode dizer sobre o perfil da demanda turística por Praia Grande, considerando o 


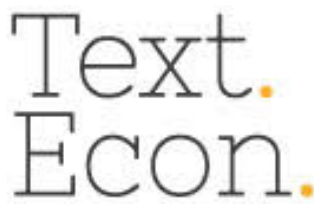

interesse despertado pelos atrativos turísticos relacionados aos cânions? A próxima seção focaliza esse assunto.

\section{BREVE CARACTERIZAÇÃO DA DEMANDA TURÍSTICA}

Não existem dados que permitam quantificar o fluxo de turistas em Praia Grande (nada para esse fim pode ser encontrado durante a pesquisa). A única possibilidade, no tocante à caracterização da demanda pelo município, prende-se ao registro de visitas em livro disponível no Portal Turístico mantido pela prefeitura. Não é possível extrair dessa fonte conclusões sobre a quantidade de turistas que se dirigem ao local, atraídos pelos cânions. É provável que número considerável de visitantes simplesmente ignore o Portal Turístico e, assim, deixe de consignar a sua presença.

Entretanto, se não há números que indiquem o volume da movimentação turística, tomar aqueles registros como uma espécie de amostra autoriza alguma ideia sobre outros aspectos da demanda. As informações prestam-se à caracterização tanto da origem dos visitantes como da distribuição temporal de suas presenças. Explora-se essa fonte na sequência, utilizando as informações do Portal Turístico de Praia Grande para o período entre março de 2016 e o final de fevereiro de 2017: doze meses, portanto, abrangendo uma alta estação turística e temporalidades intermediárias (Tabela 6). Não há razão para deixar de considerar as informações correspondentes como indicação sobre o perfil (e não sobre o número, reitere-se) do fluxo turístico local.

Tabela 6 - Praia Grande: origem dos visitantes registrados no livro do Portal Turístico entre março de 2016 e fevereiro de 2017

\begin{tabular}{|c|c|c|}
\hline Origem dos turistas & $\mathrm{N}^{\mathrm{o}}$ de turistas & $\%$ \\
\hline \multicolumn{3}{|c|}{ Turistas nacionais } \\
\hline Santa Catarina & 654 & 43,0 \\
\hline Rio Grande do Sul & 464 & 30,5 \\
\hline São Paulo & 112 & 7,4 \\
\hline Paraná & 52 & 4,0 \\
\hline Rio de Janeiro & 22 & 1,7 \\
\hline Subtotal & 1.304 & 85,6 \\
\hline \multicolumn{3}{|c|}{ Turistas internacionais } \\
\hline Argentina & 66 & 4,3 \\
\hline Uruguai & 23 & 1,5 \\
\hline Alemanha & 19 & 1,2 \\
\hline Rússia & 11 & 0,7 \\
\hline Espanha & 8 & 0,5 \\
\hline França & 8 & 0,5 \\
\hline Estados Unidos & 5 & 0,3 \\
\hline Suíça & 4 & 0,3 \\
\hline
\end{tabular}




\begin{tabular}{lcc} 
Inglaterra & 3 & 0,2 \\
Portugal & 3 & 0,2 \\
Subtotal & 150 & 9,8 \\
\hline Sem indicação de origem & 70 & 4,6 \\
\hline Total & 1.524 & 100 \\
\hline Fonte: elaborado pelos autores com base em informações obtidas junto ao Portal Turístico de \\
Praia Grande, vinculado à Secretaria de Esporte e Turismo do município
\end{tabular}

Segundo os registros, a origem nacional prevaleceu amplamente entre os visitantes, sem que isso surpreenda. Santa Catarina foi o principal estado emissor, seguido do Rio Grande do Sul e, de longe, por São Paulo. A predominância das origens sulinas reflete a proximidade geográfica, representativa de deslocamentos mais rápidos e de menores custos. Mas a atratividade dos cânions também repercute internacionalmente, como mostram as indicações sobre visitantes estrangeiros. A Argentina desponta como proveniência principal, seguida à distância pelo Uruguai, um perfil alinhado com o que ocorre no turismo estrangeiro em toda Santa Catarina.

As possibilidades para acesso rodoviário ao município contribuem para essa configuração. Durante o verão, Santa Catarina é um dos principais destinos turísticos do Cone Sul, e visitantes dos países vizinhos normalmente chegam por transporte terrestre, boa parte utilizando a rodovia BR-101. O trevo dessa rodovia que permite chegar em Praia Grande é passagem obrigatória para a maioria, e isso facilita os movimentos dos interessados nos cânions. Tal malha rodoviária também favorece a ida ao município para quem está como veranista em balneários mais ou menos próximos. Tudo isso vale para outros visitantes estrangeiros, entre os quais os alemães, russos, espanhóis e franceses compareceram em maior número no período considerado.

No tocante à distribuição temporal das chegadas, os registros no Portal Turístico indicam elevação entre o final do mês de dezembro e o final do mês de abril, período que abriga todo o verão e as maiores férias escolares (Tabela 7). Ocorre nesse intervalo, caracteristicamente, um grande fluxo de turistas nos litorais sul catarinense e norte rio-grandense, e isso alimenta a atividade turística ligada ao complexo de cânions.

Tabela 7 - Praia Grande: distribuição mensal dos registros de chegadas no Portal Turístico março de 2016 a fevereiro de 2017

\begin{tabular}{|c|c|c|}
\hline Mês e ano & $\mathrm{N}^{0}$ de registros & $\%$ \\
\hline Março de 2016 & 181 & 11,8 \\
\hline Abril de 2016 & 186 & 12,1 \\
\hline Maio de 2016 & 72 & 4,7 \\
\hline Junho de 2016 & 100 & 6,5 \\
\hline Julho de 2016 & 103 & 6,7 \\
\hline Agosto de 2016 & 49 & 3,2 \\
\hline
\end{tabular}




\begin{tabular}{lcc} 
Setembro de 2016 & 171 & 11,1 \\
Outubro de 2016 & 65 & 4,2 \\
Novembro de 2016 & 93 & 6,1 \\
Dezembro de 2016 & 68 & 4,4 \\
Janeiro de 2017 & 212 & 13,8 \\
Fevereiro de 2017 & 234 & 15,2 \\
\hline Total & 1.534 & 100
\end{tabular}

Fonte: elaborado pelos autores com base em informações obtidas junto ao Portal Turístico de Praia Grande, vinculado à Secretaria de Esporte e Turismo do município

A maior presença de registros nos meses de verão dá sentido à conjectura - a rigor, uma inferência a partir da observação - de que o turismo em Praia Grande, ligado à condição desse município como passagem para os cânions, apresenta-se em boa parte como uma extensão do turismo de veraneio que caracteriza diferentes locais da orla marítima mais ou menos próxima. De todo modo, chama a atenção o salto verificado no mês de setembro, em plena baixa estação turística. Uma possível explicação pode ser o fato de o feriado comemorativo da Independência do Brasil ter ocorrido numa quarta-feira em 2016, estimulando (e permitindo) o prolongamento do período dedicado ao lazer, talvez com incentivo à visitação dos cânions.

Estudos regionais dedicados ao turismo geralmente contemplam os reflexos socioeconômicos das atividades correspondentes. Este artigo não constitui exceção, considerando-se o que se mostrou possível fazer. A próxima seção ocupa-se do assunto.

\section{PERSCRUTANDO OS REFLEXOS SOCIOECONÔMICOS DO TURISMO}

A relação entre a atratividade da oferta turística primária do território de Praia Grande, incrustada no complexo de cânions, e a oferta turística derivada ou incorporada, associada aos serviços de hospedagem, alimentação e outros, há de ser de fortalecimento recíproco. Esse tipo de vínculo costuma ser observado em diferentes locais onde há presença do setor de turismo, sobressaindo em abordagens sobre o papel das correspondentes atividades no desenvolvimento em nível territorial.

Observe-se que alguns desses estudos lançam mão da ideia de polo turístico, em procedimento que representa adaptação do enfoque desenvolvido por Perroux (1967) há mais de meio século para a análise do desenvolvimento local ou regional associado ao funcionamento de indústrias motrizes. Nessa adaptação, o setor de turismo é visto como foco de dinamização econômica e, devido às interações, como apto a irradiar o crescimento e o desenvolvimento no seu entorno (SESSA, 1983). 
Outros estudos exploram as possibilidades do conceito de cluster turístico. A base é a inspiração representada pelas análises sobre dinâmica industrial associada à existência e ao desempenho de aglomerações setorialmente especializadas, ou clusters industriais, um tema de grande visibilidade desde, pelo menos, os anos 1980, na esteira do influente livro de Piore e Sabel (1984). Por cluster turístico entende-se, basicamente, “[...] a existência, em situação de proximidade - e sob o amálgama de atrativos naturais ou criados que magnetizam fluxos de visitantes -, de empresas de hospedagem, alimentação, entretenimento, produção cultural e serviços [turísticos] diversos [...]" (LINS, 2000, 56). Central nessa utilização da ideia de cluster é a interdependência entre os membros: “[...] a boa performance de um pode ampliar o sucesso dos outros" (PORTER, 1998, p. 81), uma relação, assinale-se, que pode se revelar também negativamente.

Tem igualmente aplicação, em abordagens que realçam a importância das interações, a noção de causação circular acumulativa, utilizada por Myrdal (1968) para discutir e sugerir iniciativas de política a respeito do desenvolvimento regional ou local, em termos gerais. Aquela ideia evoca "[...] uma constelação circular de forças, que tendem a agir e a reagir interdependentemente [...]" (MYRDAL, 1968, p. 32), e se faz presente em estudos de trajetórias tanto de expansão como de declínio econômico. A chave, como o próprio nome aponta, está no encadeamento entre causas e efeitos.

No que concerne ao turismo, os encadeamentos possíveis, numa área em que o setor opere, podem se apresentar como segue. A atração primária provoca fluxos de visitantes cujas necessidades de consumo fomentam e fazem florescer negócios vinculados, fortalecendo a base de atração e repercutindo em mais turistas. Esse aumento da procura, por sua vez, estimula a ampliação e multiplicação dos elementos da oferta derivada ou incorporada, e assim por diante. $\mathrm{O}$ crescimento da renda e das ocupações, nas atividades direta e indiretamente vinculadas ao turismo, tende a resultar em ampliação da demanda local por vários tipos de mercadorias e serviços, também reverberando nos investimentos. O setor público, chamado a participar especialmente com respeito às infraestruturas, aproveitaria as possibilidades da tributação ampliada e fortalecida e agiria para melhorar as condições de acesso, por exemplo, fortalecendo a atratividade.

Tudo isso, em espiral, evoca crescimento econômico e ampliação das oportunidades de geração de renda e emprego, permitindo falar, possivelmente, em desenvolvimento. Mas é claro que, entre a formulação teórica impregnada nessa narrativa estilizada e a realidade das diferentes experiências, a distância tende a ser variada. Numerosas circunstâncias locais e extralocais têm influência, assim como as iniciativas protagonizadas em diversos níveis. 


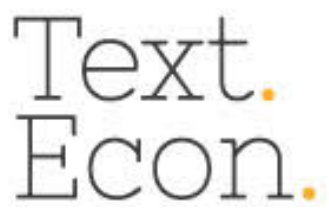

De todo modo, em Praia Grande a trajetória recente autorizaria falar em fortalecimento mútuo entre a atratividade da oferta primária, traduzida na demanda turística, e o adensamento das condições associadas aos serviços locais. A aceleração, nos últimos anos, do processo de instalação de meios de hospedagem e serviços de alimentação dá sentido a tal consideração. O município passou, inclusive, a exibir um tipo novo de atividade, surgido por conta da experiência turística, como detectado durante a pesquisa de campo que embasou este artigo. Foi criada a Lavanderia Cantinho da Limpeza, localizada no centro da cidade, com estrutura de serviços capaz de atender a demanda ligada ao turismo: a instalação teria como motivação maior o mercado dos estabelecimentos de hospedagem, o que se depreende do destaque concedido às roupas de cama na página do empreendimento na internet (LAVANDERIA CANTINHO DA LIMPEZA, [S.d.]).

Os reflexos do setor de turismo dizem notadamente respeito à multiplicação dos estabelecimentos diretamente envolvidos e dos vinculados empregos. A tabela 8 registra os números relativos aos estabelecimentos, extraídos da base de dados da RAIS. Explorando as estatísticas da Classificação de Atividades GRUP CNAE 95 ${ }^{1}$, observou-se que entre 2001 e 2016 o número agregado de estabelecimentos de hospedagem e alimentação e de agências de viagens e turismo mais que quintuplicou.

Tabela 8 - Praia Grande: $n^{\circ}$ de estabelecimentos em atividades relacionadas ao turismo Classificação GRUP CNAE 95: 2001-2016

\begin{tabular}{|c|c|c|c|c|c|c|c|c|}
\hline \multirow{2}{*}{ Setores } & \multicolumn{2}{|c|}{2001} & \multicolumn{2}{|c|}{2006} & \multicolumn{2}{|c|}{2011} & \multicolumn{2}{|c|}{2016} \\
\hline & $\mathrm{N}^{0}$ & $\%$ & $\mathrm{~N}^{0}$ & $\%$ & $\mathrm{~N}^{0}$ & $\%$ & $\mathrm{~N}^{\mathrm{o}}$ & $\%$ \\
\hline $\begin{array}{l}\text { Estabelecimentos hoteleiros e } \\
\text { outros tipos de alojamento } \\
\text { temporário }(551)\end{array}$ & 2 & 50,0 & 3 & 75,0 & 3 & 25,0 & 10 & 45,4 \\
\hline $\begin{array}{l}\text { Restaurantes e outros } \\
\text { estabelecimentos de serviços de } \\
\text { alimentação (552) }\end{array}$ & 2 & 50,0 & 1 & 25,0 & 8 & 66,7 & 10 & 45,4 \\
\hline $\begin{array}{l}\text { Atividades de agências de } \\
\text { viagem e organizadores de } \\
\text { viagens (633) }\end{array}$ & 0 & 0 & 0 & 0 & 1 & 8,3 & 2 & 9,1 \\
\hline Total & 4 & 100 & 4 & 100 & 12 & 100 & 22 & 100 \\
\hline
\end{tabular}

Trata-se, em todos os casos, de estabelecimentos "formais", isto é, em que os vínculos ocupacionais envolvem registros na Carteira de Trabalho. Cabe assinalar que na tabela 3 , onde se mostrou (seção 2) o percurso da criação de meios de hospedagem entre 1989 e 2015, constam 15

\footnotetext{
${ }^{1}$ CNAE significa Classificação Nacional de Atividades Econômicas. GRUP refere-se a um dos níveis hierárquicos de apresentação dos dados relativos às atividades, o nível de Grupo, com códigos numéricos de 3 dígitos. Consultar IBGE ([S.d.]c).
} 


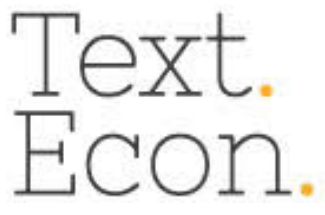

estabelecimentos. A conclusão não pode ser outra, considerando-se as informações da tabela 8: 1/3 daquelas unidades caracterizar-se-iam como "informais". O mesmo tipo de observação vale para os dados da tabela 4, sobre serviços de alimentação (também na seção 2): 12 estabelecimentos aparecem como criados entre 2000 e 2014, superando a quantidade de unidades "formais" exibida na tabela $8 . \mathrm{O}$ contraste é ainda maior no tocante às agências de viagem e turismo: a tabela 5 (igualmente na seção 2) identificou 9 desses empreendimentos, e somente 2 estão registrados na base de dados da RAIS. Numa palavra, a informalidade parece ser a regra em boa parte do, por assim dizer, trade turístico de Praia Grande.

Esse aspecto está presente também nas ocupações turísticas. A tabela 9 apresenta o número de vínculos ativos "formais", implicando Carteira de Trabalho, nos estabelecimentos de hospedagem e alimentação e nas agências de viagem e turismo, entre os anos de 2001 e 2016 . O registro total passa de 4 no primeiro ano da série para 70 no último ano. A cada cinco anos, conforme os subperíodos escolhidos para elaborar a tabela, há um grande salto nos números totais: mais que dobram entre 2001 e 2006, bem mais que triplicam entre 2006 e 2011, e mais que dobram desse último ano até 2016. O período correspondente à segunda metade da década de 2000, e daí em diante, configurou-se, de fato, como o de maior repercussão do movimento turístico ligado ao complexo de cânions na espessura da oferta derivada ou incorporada.

Tabela 9 - Praia Grande: $n^{\circ}$ de empregos formais em atividades relacionadas ao turismo vínculos ativos em 31/12 - Classificação GRUP CNAE 95: 2001-2016

\begin{tabular}{lcccccccc}
\hline \multirow{2}{*}{ Setores } & \multicolumn{2}{c}{2001} & \multicolumn{2}{c}{2006} & \multicolumn{2}{c}{2011} & \multicolumn{2}{c}{2016} \\
\cline { 2 - 9 } & $\mathrm{N}^{\mathrm{o}}$ & $\%$ & $\mathrm{~N}^{\mathrm{o}}$ & $\%$ & $\mathrm{~N}^{\mathrm{o}}$ & $\%$ & $\mathrm{~N}^{\mathrm{o}}$ & $\%$ \\
\hline $\begin{array}{l}\text { Estabelecimentos hoteleiros e } \\
\begin{array}{l}\text { outros tipos de alojamento } \\
\text { temporário (551) }\end{array}\end{array}$ & 3 & 75,0 & 9 & 100 & 22 & 66,7 & 56 & 80,0 \\
\hline $\begin{array}{l}\text { Restaurantes e outros } \\
\text { estabelecimentos de serviços de } \\
\text { alimentação (552) }\end{array}$ & 1 & 25,0 & 0 & 0 & 10 & 30,3 & 13 & 18,6 \\
\hline $\begin{array}{l}\text { Atividades de agências de } \\
\text { viagem e organizadores de } \\
\text { viagens (633) }\end{array}$ & 0 & 0 & 0 & 0 & 1 & 3,0 & 1 & 1,4 \\
\hline Total & 4 & 100 & 9 & 100 & 33 & 100 & 70 & 100 \\
\hline
\end{tabular}

Fonte: elaborado pelos autores com dados da Relação Anual de Informações Sociais (RAIS) para vários anos (MINISTÉRIO DO TRABALHO, [S.d.])

Reitere-se, todavia, a observação já feita sobre a natureza dos dados. Trata-se, na tabela 9, tão somente de vínculos "formais". Como está claro na discrepância entre, de um lado, os elencos de meios de hospedagem, serviços de alimentação e agências de viagem e turismo apresentados anteriormente, e, de outro, os números da tabela 8 , isso quer dizer que a realidade 


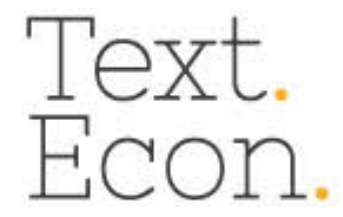

do trabalho ligado ao turismo em Praia Grande transcende em muito o que se encontra retratado na tabela 9. Se, como se falou anteriormente, a informalidade marca grande parte do trade turístico praiagrandense, os dados exibidos significam somente o "piso" da realidade do trabalho no turismo.

Com efeito, muito do quadro vigente diz respeito ao trabalho protagonizado no seio familiar, ou com utilização de pessoas (trabalhadores) sem qualquer registro, com o que isso pode representar em remuneração e direitos. Esse tipo de assunto tem atraído a atenção de pesquisadores interessados no papel do turismo como promotor do desenvolvimento regional e local, em diferentes países. Uma ilustração de abordagem nesse sentido, contemplando realidades externas ao centro do capitalismo e procurando extrair elementos capazes de contribuir para a formulação de políticas de melhoria das condições de trabalho no turismo, é Christian et al. (2011).

No Brasil, estudos sobre o significado do crescimento do setor em termos de geração de empregos, salientando especialmente a questão da qualidade e dos níveis de remuneração, podem ser encontrados para destinos turísticos em diversas regiões. Para o Nordeste, cabe mencionar o estudo de Fonseca (2002) sobre Natal (RN); para o Sul, vale assinalar Lins (1993), a propósito das transformações em uma comunidade litorânea tradicional na Ilha de Santa Catarina, a Barra da Lagoa. Em ambos sobressai a grande precariedade do trabalho turístico, de uma maneira geral. Em Praia Grande, captar a situação na sua plenitude exigiria uma investigação específica, em nível de estabelecimento turístico. Essa estratégia chegou a ser cogitada, mas foi abandonada tendo em vista, inclusive, as reações enfrentadas já nas primeiras tentativas.

Também frequente em pesquisas que procuram averiguar os reflexos socioeconômicos do turismo é a estimativa da geração de renda pelas correspondentes atividades. Turistas normalmente gastam com diárias (ou pernoites) em meios de hospedagem, com refeições e com serviços diversos, e essa receita turística circula pelos vasos comunicantes do sistema econômico local ou regional, podendo gerar renda (e também empregos e tributos, por exemplo) por conta dos efeitos multiplicadores (FIGUEROLA, 1985). Esse tipo de efeito tende a ser tanto mais observado na medida em que o sistema local-regional mostra-se mais fortemente "integrado", com importantes relações internas e poucos "vazamentos".

Não se procurou estimar esse tipo de efeito para Praia Grande. Lograr êxito em tal empreitada exigiria dispor de dados e informações cuja obtenção demandaria uma pesquisa própria, com levantamentos diretos nos vários negócios turísticos sobre as receitas e as estruturas de gastos, por exemplo. 
O que se conseguiu realizar foi somente uma tentativa de estimação das receitas turísticas dos meios de hospedagem. Foram dois os parâmetros utilizados. Um refere-se ao preço médio das diárias em cada estabelecimento, em outubro de 2017, levantado mediante consulta aos respectivos serviços de reservas. O outro diz respeito à taxa de ocupação média desse segmento da oferta turística em 2016, expressa em percentagem e extraída de pesquisa realizada pela Associação Brasileira da Indústria de Hoteis - Santa Catarina (ABIH-SC) para cada mês daquele ano. Utilizaram-se as taxas mensais informadas para os meios de hospedagem da região turística Encantos do Sul, uma das que constam da regionalização turística do governo de Santa Catarina (SANTA CATARINA, [S.d.]) - região turística que, assinale-se, não abrange Praia Grande. A taxa de ocupação média para 2016 na região Encantos do Sul foi de 46,9\%, e optou-se por utilizá-la para Praia Grande em virtude da "proximidade". Os dados que entraram no cálculo dessa média estão disponíveis na referida Associação Brasileira da Indústria de Hotéis - Santa Catarina (ABIH-SC, [S.d])

A tabela 10 apresenta o exercício realizado. Com a cautela imposta pela limitação dos dados e pelas aproximações efetuadas, envolvendo indicadores produzidos para situações somente próximas - temporal (ano de 2016) e geograficamente falando (taxa de utilização da capacidade de hospedagem na região Encantos do Sul) - , e com as incertezas inerentes à utilização de informações obtidas via consultas telefônicas (valor das diárias em outubro de 2017). Observa-se que, no ano de 2017, o conjunto de equipamentos de hospedagem instalados em Praia Grande até 2015 teria obtido uma receita agregada de mais ou menos US\$ 3,5 milhões. Um único estabelecimento teria concentrado $40 \%$ desse montante: a pousada Refúgio Ecológico Pedra Afiada, surgida em 2001. Trata-se de empreendimento com origem externa à área, e com a maior capacidade de hospedagem entre todos os estabelecimentos até então repertoriados (10 unidades habitacionais e 62 leitos, como indicado na tabela 3, mostrada anteriormente). Também o seu nível tarifário é (e de longe) o mais elevado.

Para uma ideia aproximada do significado daquele valor, cabe tentar uma associação com o Produto Interno Bruto municipal, objetivando tão somente cotejar a ordem de grandeza. Nas estatísticas do IBGE, o valor do PIB de Praia Grande para o período mais próximo da realização do presente estudo corresponde a 2015: R\$ 128, 3 milhões (IBGE, [S.d.]d). Convertendo para dólares dos Estados Unidos, pela taxa média de câmbio daquele ano (R\$ 3,331 para cada US\$, calculada com base nos dados disponíveis em Instituto de Economia Gastão Vidigal ([S.d.]), o valor atingiu US\$ 38,5 milhões. Assim, a receita anual, estimada para 2017, do conjunto dos meios de hospedagem relacionados na tabela 10 equivaleria a cerca de $9 \%$ do valor do PIB municipal. Pode-se conjecturar que, caso se adicionem as receitas dos demais serviços turísticos, 


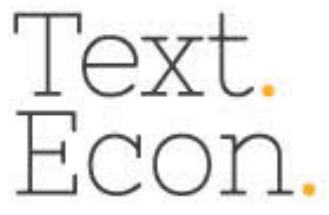

http://dx.doi.org/10.5007/2175-8085.2018v21n2p119

obtém-se uma representatividade da economia do turismo em Praia Grande correspondente a valor situado entre $10 \%$ e $15 \%$ do PIB municipal.

Esse esforço para captar, mesmo que precariamente, os efeitos socioeconômicos da expansão do turismo em Praia Grande está em linha com atividades de pesquisa acadêmica e formulação de políticas que exibem manifestações em diferentes contextos e exploram vários ângulos teóricos. Para ficar somente na América Latina, vale assinalar, sobre o papel exercido pelo turismo no desenvolvimento em escala urbana, os estudos de Wallingre (2010) sobre a cidade de Federación, na província argentina de Entre Ríos, e de Matovelle e Baez (2018) sobre Quito. Pesquisas sobre o tema têm atingido nível de especificação intraurbano, como ilustrado pelo trabalho de Mano, Mayer e Fratucci (2017) a respeito do turismo na favela Santa Marta, no Rio de Janeiro, cuja ênfase recai no aspecto relativo à base comunitária da atividade turística.

Tabela 10 - Praia Grande: estimativa de receita anual (para 2017) dos equipamentos de hospedagem instalados até 2015

\begin{tabular}{|c|c|c|c|c|c|}
\hline Meio de hospedagem & $\begin{array}{l}\text { Unidade } \\
\text { habita- } \\
\text { cional }\end{array}$ & $\begin{array}{l}\text { Capaci- } \\
\text { dade de } \\
\text { hosped. } \\
\text { anual (A } \\
\text { x } 365 \\
\text { dias) } \\
\text { (B) }\end{array}$ & $\begin{array}{c}\text { Estimat. do } \\
\text { uso anual } \\
\text { da capac. } \\
\text { de hosped. } \\
\text { (B x } 0,469 \text { ) } \\
\text { (C) }\end{array}$ & $\begin{array}{l}\text { Valor } \\
\text { médio da } \\
\text { diária em } \\
\text { outubro } \\
\text { de } 2017 \\
\text { (US\$) } \\
\text { (D) }\end{array}$ & $\begin{array}{c}\text { Estimativa } \\
\text { de receita } \\
\text { anual } \\
\text { (US\$) } \\
\text { (C x D) } \\
\text { (E) }\end{array}$ \\
\hline Hotel do Sérgio & 14 & 5.110 & 2.397 & 62,4 & 149.573 \\
\hline Pousada Colina da Serra & 6 & 2.190 & 1.027 & 141,7 & 145.526 \\
\hline Refúgio Ecológico Pedra afiada & 19 & 6.935 & 3.252 & 442,9 & 1.440 .311 \\
\hline Costão Fortaleza Lodge & 5 & 1.825 & 856 & 180,3 & 105.656 \\
\hline Morada dos Canyons & 10 & 3.650 & 1.712 & 315,2 & 539.622 \\
\hline Nativo dos Canyons & 4 & 460 & 685 & 53,3 & 36.510 \\
\hline Praia Grande Hotel & 15 & 5.475 & 2.568 & 47,0 & 120.696 \\
\hline Resort dos Canyons & 3 & 1.095 & 514 & 56,4 & 28.990 \\
\hline Pousada Malacara & 11 & 4.015 & 1.883 & 150,8 & 283.956 \\
\hline Pousada Pacatatu & 5 & 1.825 & 856 & 72,1 & 61.718 \\
\hline Pousada Aracema & 12 & 4.380 & 2.054 & 109,8 & 225.529 \\
\hline Pousada Lima & 7 & 2.555 & 1.198 & 37,6 & 45.045 \\
\hline Refúgio das montanhas & 5 & 1.825 & 856 & 129,3 & 110.681 \\
\hline Pousada Itaimbé & 8 & 2.920 & 1.369 & 101,9 & 139.501 \\
\hline Hospedaria Regional Beija Flor & 3 & 1.095 & 514 & 67,4 & 34.644 \\
\hline Total & 127 & 46.355 & 21.740 & & 3.467 .958 \\
\hline
\end{tabular}

Fontes:elaborado pelos autores com dados e informações provenientes das seguintes fontes: para a relação dos meios de hospedagem e a capacidade de hospedagem, a Prefeitura de Praia Grande ([S.d.]a); para a estimativa do uso anual da capacidade hospedagem, a taxa média de ocupação de meios de hospedagem da região turística Encantos do Sul, derivada dos dados disponíveis em ABIH-SC ( [S.d]); para o valor das diárias, consulta telefônica aos serviços de reservas dos estabelecimentos de hospedagem.

Obs.: o valor das diárias foi convertido para dólares dos Estados Unidos pela taxa de câmbio média R \$/US\$ do mês de outubro de 2017, para venda da moeda estadunidense, conforme o Banco Central do Brasil (BCB, [S.d]). A taxa média calculada é de R\$3,1889 por US\$. 
Realçando a questão dos recortes conceituais utilizados, é importante indicar a presença, com alguma frequência, da já apresentada ideia de cluster turístico. A investigação de Ribeiro e Andrade (2015) procura caracterizar esse tipo de configuração no plano brasileiro, não sem comentar a sua importância quer para o crescimento turístico em si, quer para a dinamização da economia nos ambientes envolvidos, haja vista as interações e interdependências costumeiramente observadas. De algum modo vinculado à exploração das possibilidades analíticas e de elaboração de política outorgadas pela forma cluster, deve-se mencionar o debate sobre desenvolvimento local e endógeno no sentido realçado por Vázquez Barquero (2001, p. 10), para quem, “[...] em última análise, são as iniciativas e o controle exercidos pelos atores locais e a sociedade civil, através de suas respostas estratégicas, que contribuem para os processos de transformação de cidades e regiões." Representam ilustrações os estudos realizados por Scótolo e Netto (2015) - que discutem no plano conceitual o desenvolvimento local apoiado no turismo - e por Silveira (2005) - que especifica a importância da forma cluster turístico nas estratégias de desenvolvimento local.

Destaquem-se ainda as referências ao turismo nos debates sobre o desenvolvimento territorial rural, de matriz em grande medida francesa, mas com ilustrações em diferentes países. Na discussão “original”, Pecqueur (2001), por exemplo, trata o turismo - turismo rural, agroturismo - como integrante da "cesta de bens e serviços" decorrente das estratégias dos agentes do território destinadas à disponibilização de uma oferta variada localmente. Estes se revelam articulados e complementares, e com aspectos históricos e culturais incrustados. Para estudo sobre experiência no Brasil, elaborado com inspiração do referido debate, pode-se consultar Lins (2016), que aborda o agroturismo nas Encostas da Serra Geral, no sudeste de Santa Catarina, e o turismo vinculado a pousadas e hoteis fazenda na Região Serrana desse estado.

$\mathrm{Na}$ próxima parte dirige-se a atenção ao assunto referente às ações institucionais de planejamento e promoção do turismo em Praia Grande. Essa é a órbita em que, de uma maneira geral, os agentes diretamente envolvidos com o setor costumam interagir com vistas a fortalecer as práticas existentes e descortinar novas possibilidades.

\section{PLANEJAMENTO E PROMOÇÃO DO TURISMO EM PRAIA GRANDE}

Destinos turísticos podem surgir mais ou menos espontaneamente, mas a manutenção e o aprimoramento das suas condições dependem de ações conjuntas, enlaçando esferas institucionais e os integrantes do trade. Agir nesse sentido contribui, e parece mesmo condição 
necessária, para evitar o declínio desses destinos, um processo teorizado por Butler (1980) com base na ideia de ciclos de evolução das áreas turísticas. Promoção e, especialmente, planejamento, envolvendo diferentes agentes e atores dos territórios implicados, são necessidades incontornáveis, como várias experiências internacionais ajudam a ilustrar, entre elas as de localidades da Comunidade Valenciana, na Espanha, estudadas por Nácher e Carpi $(2000)^{2}$.

Entre as iniciativas importantes nesse sentido figura a definição de calendários de atividades cuja realização possa seduzir visitantes e resultar em fluxos turísticos distribuídos no tempo. No Brasil, a situação observada na região serrana do Rio Grande do Sul, particularmente no município de Gramado, é ilustrativa a respeito (BORTNOWSKA; ALBERTON; MARINHO, 2012). A notável expansão do setor de turismo naquela localidade guarda estreita relação com o crescimento do turismo de eventos, dos quais o Natal Luz, além do Festival de Cinema, é provavelmente o mais conhecido e divulgado (GEVEHR; VIDAL; NANDI, 2014).

A página na internet da Associação dos Municípios do Extremo Sul de Santa Catarina (AMESC, 2016) apresenta a relação dos eventos programados em cada município da região, no ano de 2016. Para 2017 não havia indicação de eventos, mas pode-se considerar que a sequência do ano anterior se repetiu, pois trata-se, na maioria, de festejos tradicionais. Para Praia Grande aparecem indicados: Festa de São Sebastião (padroeiro do município), em janeiro; Festa de Emancipação Política e Administrativa, em julho; Procissão de São Cristovão, também em julho; Romaria de São Roque (Comunidade Quilombola), em agosto; Semana Farroupilha, em setembro; Rodeio Crioulo Nacional, em outubro; Natal dos Canyons, em dezembro.

Em 2017, as competições de Boia Cross voltaram a acontecer após interrupção de seis anos (PITHAN, 2017). Realizadas costumeiramente no mês de abril, e foco de atração de numerosos visitantes, sua interrupção duradoura deveu-se a alegados problemas com segurança e outros, tendo a retomada ocorrido sob uma nova roupagem e com segurança reforçada. Note-se ainda que costumam ser protagonizados diversos outros eventos, relacionados a esportes de aventura como mountain bike, rapel e base jump. Todavia, representam iniciativas dos próprios praticantes, geralmente sem divulgação pela administração do município.

Em relação ao planejamento e execução de atividades de promoção do turismo local ou regional, cabem pelo menos três referências sobre Praia Grande. Uma delas envolve ações de cunho mais local, e as outras, conexões mais amplas em termos institucionais e espaciais.

\footnotetext{
${ }^{2}$ Comparando destinos turísticos da ComunidadeValenciana, na costa mediterrânica espanhola - Benicàssim, Gandía, Denia, Xàbia e Benidorm -, Nácher e Carpi (2000) mostraram que as trajetórias mais intensamente permeadas de ações coletivas e cooperativas revelaram-se mais bem sucedidas, inclusive - talvez principalmente -, quando se tratou de enfrentar situações ou períodos adversos.
} 
Uma dessas referências tem a ver com o projeto denominado Rota dos Sabores, objeto de convênio firmado em 2014 entre a Prefeitura Municipal de Praia Grande e o Ministério do Turismo (PREFEITURA DE PRAIA GRANDE, 2016). Visando estabelecer um roteiro turístico com o envolvimento de propriedades rurais do município, as ações contemplam a integração entre visitantes e produtores rurais, artesãos e estabelecimentos gastronômicos escolhidos por conta da sua tradição culinária e do uso de alimentos produzidos ecologicamente. A pretensão é criar novas opções turísticas, diversificando a oferta, e propiciar aumento de renda para os produtores participantes. Com execução iniciada em 2015, e em processo continuado de capacitação dos participantes, o roteiro contava com 12 famílias envolvidas no final de 2017 (MUNICÍPIO DE PRAIA GRANDE, 2017)

Outra referência no tocante ao planejamento e à promoção do turismo em Praia Grande diz respeito ao Plano Estratégico de Desenvolvimento do Turismo na Região das Serras Gaúcha e Catarinense (BRASIL, 2015), iniciado em 2015 sob os auspícios do Ministério do Turismo como parte do Programa de Apoio ao Desenvolvimento Regional do Turismo (PRODETUR). No Rio Grande do Sul, são 14 municípios implicados, de quatro regiões turísticas diferentes. Em Santa Catarina, o total de municípios é 9, todos localizados mais ou menos perto da área dos cânions, sendo Praia Grande o mais próximo.

Mirando o estabelecimento de alianças estratégicas entre os municípios, e almejando resultados em escala de região, esse plano tem como grande objetivo o desenvolvimento de um turismo não só sustentável, mas também apto a proporcionar retornos financeiros importantes para os empreendimentos participantes. Desde a elaboração do plano, em 2015, iniciativas vinculadas foram registradas em Praia Grande, entre elas a definição e o uso da marca "Cidade dos Canyons" para identificar a localidade. De 2016 em diante, tal símbolo passou a marcar as referências ao turismo no município, em folders, placas e documentos oficiais.

O projeto Geoparque Caminhos dos Cânions do Sul, elaborado e executado no âmbito do Ministério das Minas e Energia pelo Serviço Geológico do Brasil (BRASIL, 2011), consiste em mais uma referência sobre planejamento e execução de ações para promover o turismo em Praia Grande. Seu objetivo é transformar em área de preservação permanente toda a superfície do Parque Nacional da Serra Geral e do Parque Nacional de Aparados da Serra. Previa-se a inclusão de 19 municípios ligados a essas formações de cânions.

Assinale-se que esse projeto vincula-se à Rede Global de Geoparques Nacionais, criada em 2004 pela Organização das Nações Unidas para a Educação, a Ciência e a Cultura (UNESCO), esfera em que se definem as condições de participação dos municípios. Preservar o patrimônio geológico, com métodos de conservação eficazes, educar a população sobre temas 


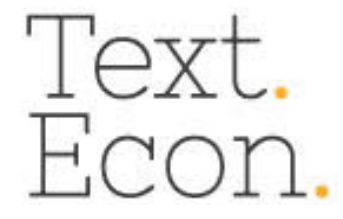

geológicos e ambientais e assegurar o desenvolvimento sustentável perfilam-se como exigências. Vale indicar que o projeto Geoparque Caminhos dos Canyons do Sul passava por alterações em 2017, sobretudo com respeito à área de abrangência (implicando a exclusão de alguns municípios) e também ao cronograma (PROJETO, 2017).

\section{CONSIDERAÇÕES FINAIS}

Como tantos outros locais no Brasil ou no exterior que possuem atributos turisticamente atrativos, o complexo de cânions na fronteira entre Santa Catarina e Rio Grande do Sul tem sido objeto de visitação e exibe destaque nos roteiros turísticos do sul do país. O realce concedido a esse patrimônio paisagístico e ambiental, em ações protagonizadas até em escala nacional, inscreve-se nessa condição e, ao mesmo tempo, constitui indicativo sobre a importância atribuída a essa estrutura física e natural e ao associado movimento turístico em diferentes níveis institucionais.

$\mathrm{Na}$ face catarinense desse complexo, que abriga dois parques nacionais transfronteiriços, o município de Praia Grande aparece implicado na movimentação dos interessados no ecoturismo e no turismo de aventuras, principais modalidades proporcionadas pelos cânions. De escassas possibilidades locais para reprodução social, um problema que se reflete em longa trajetória de contração demográfica, Praia Grande vem tendo no seu papel de passagem quase obrigatória para a área de cânions um forte estímulo à ampliação da oferta turística (derivada da oferta primária incrustada nos referidos atributos naturais). Esta se relaciona, principalmente, a serviços de hospedagem e alimentação, com repercussões também em agências de viagens e turismo e em outros serviços (guias, opções de lazer e entretenimento, esportes).

É desta forma, essencialmente, que Praia Grande se caracteriza como destino turístico: trata-se de "meta" intermediária, mas, não obstante, com importância no universo turístico desse território, por representar acesso aos parques e proporcionar acolhimento aos visitantes. Essa condição permitiria falar de uma certa economia do turismo presente no município e na sua região. Meios de hospedagem e serviços de alimentação e organização de viagens se multiplicaram, resultando em ocupações - que incluem trabalho com vínculos formais e, aparentemente na maioria dos casos, relações no âmbito familiar - e, provavelmente, em recursos financeiros decorrentes de consumo turístico. Esses recursos hão de circular, em alguma proporção, no próprio território: não é plausível que, por exemplo, em área de grande população 


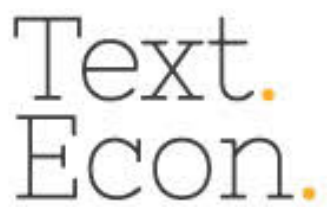

rural e atividades associadas, hotéis, pousadas, restaurantes e lanchonetes deixem de se abastecer em alimentos localmente, ao menos em algum grau.

O significado socioeconômico do turismo em Praia Grande poderá ser melhor apreciado em futuro não muito distante. O próximo Censo Demográfico haverá de permitir conclusões sobre o quanto, após uma década de proliferação de serviços turísticos ligados a investimentos até com origem extra local, as novas oportunidades criadas terão repercutido no (ou contribuído para o) estancamento da duradoura tendência de redução demográfica no município produzida pela evasão populacional.

De todo modo, planejar e promover o turismo são práticas a serem introduzidas ou fortalecidas em Praia Grande, em quaisquer circunstâncias. Buscar uma fértil articulação local entre os integrantes do trade turístico e a administração pública, objetivando robustecer explorando mais adequadamente o que se apresenta, pelo menos, como potencial - a condição do município como destino turístico intermediário na rota para o complexo de cânions, constitui iniciativa estratégica. É essencial agir coletivamente nesse sentido em escala territorial, pois condutas dessa natureza tendem a produzir benefícios para o sistema local como um todo. Comportamentos com tal perfil podem inclusive prevenir e coibir práticas capazes de comprometer a atratividade do conjunto, algo colocado em evidência no debate sobre clusters turísticos, especialmente quando a ênfase recai no problema da governança e no papel das instituições (LINS, 2007).

É necessário reconhecer, como fizeram Nácher e Carpi (2000, p. 262) com base em estudo (já mencionado) sobre localidades da Comunidade Valenciana, a "[...] importância adquirida pelo controle relativo da própria população sobre o seu processo de desenvolvimento e o estabelecimento inicial de uma cooperação estável entre todos os agentes implicados". Condutas dessa natureza apresentar-se-iam frutíferas em Praia Grande, certamente, pelo que o fortalecimento do setor de turismo pode vir a representar em uma socioeconomia historicamente necessitada de estímulos e oportunidades.

Contribuem para uma atmosfera mais impregnada de ações coletivas e colaborativas, em Praia Grande, providências como a registrada em novembro de 2017, quando a Secretaria de Turismo do município efetuou reunião com representantes do trade turístico local. O objetivo declarado era atingir uma melhor e mais profícua articulação entre os interessados no desenvolvimento do setor, para o que projetos foram apresentados, ações foram indicadas e ideias de parcerias foram anunciadas (SECRETARIA, 2017). Se mantido e intensificado, esse tipo de prática, de índole estratégica sob quaisquer pontos de vista, haverá de contribuir para o 


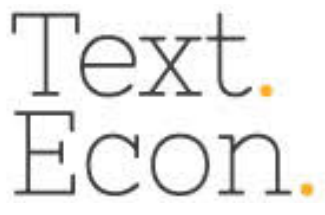

http://dx.doi.org/10.5007/2175-8085.2018v21n2p119

fortalecimento do setor turístico praiagrandense e, talvez, para a disseminação, social e espacialmente falando, de seus reflexos econômicos e sociais.

No mesmo movimento, uma melhor estruturação institucional do setor turístico poderá representar, para pesquisadores interessados na experiência de Praia Grande, menores dificuldades para a realização de estudos, comparativamente ao que foi enfrentado pelos autores deste artigo. O maior problema foi a escassez quase absoluta de dados e informações minimamente sistematizados, forçando tentativas de vislumbre e exploração - nem sempre bem sucedidas, o que não deixou de provocar alguma frustração - de diferentes possibilidades. Assim, trabalhos futuros que examinem, por exemplo, a trajetória turística impulsionada pelo que parece se desenhar com o envolvimento mais efetivo e coletivo dos agentes do setor - em torno do discernimento de novas possibilidades e na sua promoção -, poderão, talvez, produzir resultados mais rapidamente e com menores obstáculos.

\section{REFERÊNCIAS BIBLIOGRÁFICAS}

ABIH-SC - Associação Brasileira da Indústria de Hotéis - Santa Catarina. Taxa de ocupação do ano de 2016. Florianópolis: ABIH-SC, [S.d.]. Obtido em: http://www.abihsc.com.br/noticia/582/taxa-de-ocupacao-do-ano-de-2016-abihsc\#.WjqPqIWcHIU Acesso em: 20 dez 2017.

AMESC - Associação dos Municípios do Extremo Sul Catarinense. Calendário regional de eventos - 2016. [S.1.], 28 jan. 2016. Obtido em: http://www.amesc.com.br/cms/pagina/ver/codMapaItem/71107 Acesso em: 22 dez. 2017.

BCB - Banco Central do Brasil. Cotações e boletins. Brasília: BSC, [S.d.]. Obtido em: http://www4.bcb.gov.br/pec/taxas/port/ptaxnpesq.asp?id=txcotacao Acesso em: 20 dez. 2017.

BRASIL. Ministério das Minas e Energia. Projeto Geoparque Caminhos dos Cânions do Sul (Proposta). Brasília: Ministério das Minas e Energia, Serviço Geológico do Brasil (CPRM), 2011. Obtido em: http://www.cprm.gov.br/publique/media/gestao_territorial/geoparques/canions/creditos.html Acesso em: 22 dez. 2012.

BRASIL. Ministério do Turismo. Plano estratégico de desenvolvimento do turismo na região das serras gaúcha e catarinense. Brasília: Ministério do Turismo, Banco Interamericano de Desenvolvimento, $2015 . \quad$ Obtido em: http://www.turismo.gov.br/sites/default/turismo/DPROD/Contrato BID 2229 UCP/Plano Serra s Gaucha e Catarinense/Plano Estrategico Aparados Serra.pdf Acesso em: 22 dez. 2017.

BORTNOWSKA, K.; ALBERTON, A.; MARINHO, S. V. Cultura e alimentação: análise das festas gastronômicas na Serra Gaúcha - RS. Rosa dos Ventos, v. 4, n. 3, p. 369-383, 2012.

BRIGHTWELL, M. das G. S. L. Os parques nacionais de Aparados da Serra e Serra Geral e o município de Praia Grande/SC: dimensões escalares e conflitos. 159 f. Dissertação (Mestrado em Geografia) - Universidade Federal de Santa Catarina, Florianópolis, 2006.

BUTLER, R. W. The concept of a tourist area cycle of evolution: implications for management of resources. Canadian Geographer, v. 24, n. 1, p. 5-12, 1980. 
CHRISTIAN, M.; FERNANDEZ-STARK, K.; AHMED, G.; GEREFFI, G. The tourism global value chain: economic upgrading and workforce development. Durham: Center on Globalization, Governance \& Competitiveness, Duke University, 2011. Obtido em: https://gvcc.duke.edu/wp-content/uploads/2011-11-11_CGGC_Ex.Summary Tourism-GlobalValue-Chain.pdf Acesso em: 07 maio 2018.

ENCONTRASC.

[S.1.],

[S.d.].

Obtido

em: http://www.encontrasantacatarina.com.br/mapas/mapa-de-santa-catarina.htm. Acesso em: 01 out. 2017.

FIGUEROLA, M. Teoría económica del turismo. Madrid: Alianza Editorial, 1985.

FONSECA, M. A. P. da. Turismo e trabalho em áreas periféricas. Scripta Nova, v. 6, n. 119(128), [S.p.], 2002. Obtido em: http://www.ub.edu/geocrit/sn/sn119128.htm Acesso em: 07 maio 2018.

GEVEHR, D. L.; VIDAL, R. P.; NANDI, A. Natal Luz de Gramado: um patrimônio cultural da comunidade promovendo desenvolvimento regional na Serra Gaúcha. Revista Brasileira de Desenvolvimento Regional, v. 2, n. 1, p. 197-221, 2014.

GOVERNO DE SANTA CATARINA. Secretaria de Estado da Fazenda. Valor Adicionado dos Municipios.

Florianópolis:

[S.d.].

Obtido

em:

http://www.sef.sc.gov.br/servicos/servico/92/Valor_adicionado_por_munic\%C3\%ADpio_e ativi dade Acesso em: 22 dez. 2017.

HOBOLD, P. A história de Araranguá: reminiscências desde os primórdios até o ano de 1930. Araranguá: Palmarinca, 1994.

IBGE - Instituto Brasileiro de Geografia e Estatística. Censo demográfico. Vários anos.

IBGE - Instituto Brasileiro de Geografia e Estatística. Valor Adicionado Bruto a preços correntes (Mil Reais). Ano - 2015. [S.1.]: [S.d.]a. Obtido em: https://sidra.ibge.gov.br/tabela/5938 Acesso em: 22 dez. 2017.

IBGE - Instituto Brasileiro de Geografia e Estatística. Produção Agrícola Municipal: culturas temporárias e permanentes. [S.1.]: [S.d.]b. Obtido em: https://www.ibge.gov.br/estatisticasnovoportal/economicas/agricultura-e-pecuaria/9117-producao-agricola-municipal-culturastemporarias-e-permanentes.html?edicao $=9118 \& \mathrm{t}=$ downloads Acesso em: 22 dez. 2017.

IBGE - Instituto Brasileiro de Geografia e Estatística. Introdução à Classificação Nacional de Atividades Econômicas - CNAE Versão 2.0 - Subclasses para uso da administração pública. [S.1.]: [S.d.]c. Obtido em: https://concla.ibge.gov.br/images/concla/documentacao/CNAE20_Subclasses_Introducao.pdf Acesso em: 07 maio 2018.

IBGE - Instituto Brasileiro de Geografia e Estatística. Produto Interno Bruto a preços correntes (Mil Reais) - Ano 2015. [S.1.]: [S.d]d. Obtido em: https://sidra.ibge.gov.br/tabela/5938 Acesso em: 22 dez. 2017.

INSTITUTO DE ECONOMIA GASTÃO VIDIGAL. Média mensal da cotação do dólar comercial para venda. São Paulo: IEGV, [S.d.]. Obtido em: http://economia.acspservicos.com.br/indicadores_iegv/iegv_dolar.html Acesso em: 12 dez 2017.

KRIPPENDORF, J. Sociologia do turismo. Rio de Janeiro: Civilização Brasileira, 1989.

LAVANDERIA CANTINHO DA LIMPEZA. Praia Grande: Lavanderia Cantinho da Limpeza, [S.d.]. Obtido em: https://www.facebook.com/Lavanderia-Cantinho-da-Limpeza409301259127174/ Acesso em: 05 nov. 2017. 
LINS, H. N. Herança açoriana e turismo na Ilha de Santa Catarina. Geosul, v. 10, n. 14, p. 89$117,1993$.

LINS, H. N. Florianópolis, cluster turístico? Turismo em Análise, v. 11, n. 2, p. 55-70, 2000.

LINS, N. N. Interações, aprendizagem e desenvolvimento: ensaio sobre o turismo em Florianópolis. Turismo - Visão e Ação, v. 9, n. 1, p. 107-120, 2007.

LINS, H. N. A pós-modernidade e sua narrativa: o setor de turismo em debate. Acta Scientiarum. Human and Social Sciences, v. 35, n. 1, p. 37-47, 2013.

LINS, H. N. Desenvolvimento territorial rural: alguns termos do debate, sistemas agroalimentares localizados e agroturismo. Economia-Ensaios, v. 30, n. 2, p. 207-229, 2016.

LINS, H. N.; SANTOS, L. C. dos. Processos econômicos recentes no Extremo Sul de Santa Catarina: um ensaio. Textos de Economia, v. 16, n. 1, p. 36-67, 2013.

MAPA DE PRAIA GRANDE - SC. [S.d.], [S.1.]. Obtido em: https://mapasapp.com/mapa/santacatarina/praia-grande-sc/. Acesso em: 01 out. 2017.

MATOVELlE, P. A. T.; BAEZ, S. Medição da experiência turística em Quito. Revista Brasileira de Pesquisa em Turismo, v. 12, n. 1, p. 133-156, 2018.

MANO, A. D.; MAYER, V. F.; FRATUCCI, A. C. Turismo de base comunitária na favela Santa Marta (RJ): oportunidades sociais, econômicas e culturais. Revista Brasileira de Pesquisa em Turismo, v. 11, n. 3, p. 413-435, 2017.

MINISTÉRIO DO TRABALHO. Relação Anual de Informações Sociais (RAIS). Brasília: Ministério do Trabalho, [S.d.]. Obtido em: http://www.mte.gov.br. Acesso em: 15 set. 2017.

MINISTÉRIO DO TURISMO. A beleza dos cânions de Santa Catarina. Brasília: Ministério do Turismo, 2017. Obtido em: http://www.turismo.gov.br/últimas-notícias/7555-a-beleza-doscânions-de-santa-catarina.html Acesso em: 14 maio 2018.

MUNICÍPIO DE PRAIA GRANDE. Rota Sabores dos Canyons é apresentada em Porto Alegre. Centro de Informações Turísticas, 15 ago. 2017. Obtido em: http://www.praiagrande.sc.gov.br/noticias/index/ver/codNoticia/440417 Acesso em: 22 dez. 2017.

MYRDAL, G. Teoria econômica e regiões subdesenvolvidas. $2^{\mathrm{a}}$ ed. Rio de Janeiro: Saga, 1968.

NÁCHER, J. M.; CARPI, J. T. Aprender de uma región ganhadora: turismo de masas y desarrollo local em la Comunidad Valenciana (España). Estudios y Perspectivas en Turismo, v. 9, n. 3-4, p. 251-264, 2000.

PECQUEUR, B. Qualité et développement territorial: l'hypothèse du panier de biens et de services territorialisés. Économie Rurale, v. 261, p. 37-49, 2001.

PERROUX, F. A economia do século XX. Lisboa: Herder, 1967.

PIORE, M. J.; SABEL, C. F. The second industrial divide: possibilities for prosperity. New York: Basic Books, 1984.

PITHAN, S. Com nova roupagem, Boia Cross ressurge após seis anos em Praia Grande. W3, 5 abr 2017. Obtido em: https://www.revistaw3.com.br/entretenimento/2017/04/05/com-novaroupagem-boia-cross-ressurge-apos-seis-anos-em-praia-grande.html Acesso em: 22 dez. 2017.

PNUD - Programa das Nações Unidas para o Desenvolvimento; FUNDAÇÃO JOÃO PINHEIRO; IPEA - Instituto de Pesquisa Econômica Aplicada. Atlas do Desenvolvimento Humano no Brasil. [S.1.]: PNUD, Fundação João Pinheiro, IPEA, 2013. Obtido em: www.atlasbrasil.org.br/2013/pt/ranking Acesso em: 16 dez 2017. 


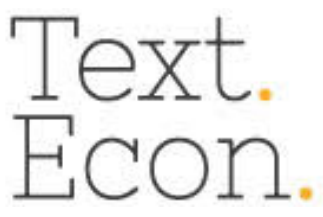

PORTER, M. Clusters and the new economics of competition. Harvard Business Review, v. 76, n. 6, p. 77-90, 1998.

PREFEITURA DE PRAIA GRANDE. Rota Sabores dos Canyons. Praia Grande: Prefeitura de Praia Grande, Ministério do Turismo, 2016. Obtido em: http://www.rotasaboresdoscanyons.com.br/ Acesso em: 22 dez. 2017.

PREFEITURA DE PRAIA GRANDE. Hospedagem. Praia Grande: Prefeitura de Praia Grande, [S.d.]a. Obtido em: http://www.praiagrande.sc.gov.br/turismo/item/Hospedagem Acesso em: 26 ago. 2017.

PREFEITURA DE PRAIA GRANDE. Gastronomia. Praia Grande: Prefeitura de Praia Grande, [S.d.]b. Obtido em: http://www.praiagrande.sc.gov.br/turismo/item/Gastronomia Acesso em: 26 ago. 2017.

PREFEITURA DE PRAIA GRANDE. Serviços Turísticos. Praia Grande: Prefeitura de Praia Grande, [S.d.]c. Obtido em: :http://www.praiagrande.sc.gov.br/turismo/item/servicos/537/Guias+de+Turismo+e+Condutores Acesso em: 26 ago. 2017.

PROJETO Geoparque Caminhos dos Cânyons do Sul tem cronograma redefinido. W3, 16 ago. 2017. Obtido em: https://www.revistaw3.com.br/geral/2017/08/16/projeto-geoparque-caminhosdos-canions-do-sul-tem-cronograma-redefinido.html Acesso em: 22 dez. 2017.

RIBEIRO, L. C. de S.; ANDRADE, J. R. de L. Characterization of tourism clusters in Brazil. Tourism Economics, v. 21, n. 5, p. 957-976, 2015.

RONSANI, G. Praia Grande: cidade dos canyons. Praia Grande: Editora Própria, 1999.

SANTA CATARINA. Encantos do sul - descubra Santa Catarina. Florianópolis: SANTUR, [S.d.]. Obtido em: http://turismo.sc.gov.br/destinos/encantos-do-sul/ Acesso em: 20 dez. 2017.

SCÓTOLO, D.; NETTO, A. P. Contribuição do turismo para o desenvolvimento local. Revista de Cultura e Turismo, v. 9, n. 1, p. 36-59, 2015.

SECRETARIA de Turismo de Praia Grande realiza reunião para apresentar os projetos. Informativo Regional, 16 nov. 2017. Obtido em: http://www.informativoregional.net/geral/secretaria-de-turismo-de-praia-grande-realizareuni\%C3\%A3o-para-apresentar-os-projetos-1.2001158 Acesso em: 23 dez. 2017.

SESSA, A. Turismo e política de desenvolvimento. Porto Alegre: Uniontur, 1983.

SILVEIRA, M. A. T. da. Turismo e estratégias de desenvolvimento local. Interações - Revista Internacional de Desenvolvimento Local, v. 7, n. 1, p. 129-140, 2005.

VÁZQUEZ BARQUERO, A. Desenvolvimento endógeno em tempos de globalização. Porto Alegre: Fundação de Economia e Estatística, 2001.

WALLINGRE, N. Contribuição do turismo ao desenvolvimento local: evolução experimentada na cidade de Federação, Argentina. Turismo em Análise, v. 21. N. 3, p. 539-566, 2010. 